\title{
A arquitetura, 0 corpo e 0 espelho \\ sobre a beleza e o tempo na arte \\ do Renascimento e em nossos dias*
}

Mário Henrique Simão D’Agostino

Plutarco, em “V ida de Péricles” (1958, p. 390), ao descrever as vicissitudes da prodigiosa empresa arquitetônica e urbanística de remodelação da acrópole de A tenas, exprime a ventura e a magnificência do feito como um cancelamento do tempo consumado pela beleza. " $N$ as obras de Péricles", expõe 0 autor, "floresce como que uma juventude perene; essas se conservam à visão indenes ao tempo, quase possuem infuso um ar sempre fresco e uma alma que não conhece velhice".

Pronunciadas há mais de cinco séculos do empreendimento, tais palavras ganham tom e intensidade singulares. $A$ fórmula, todavia, não era inédita. Para aquém da sistematização helenística da "doutrina das ordens arquitetônicas", da analogia entre a beleza dos corpose a dos templos perquirida pelos arquitetosna G récia clássica, a exaltação da eterna juventude dos corpos belos, " flor que não murcha" , arraigava-se em pleno no mais longevo solo do mito. JeanPierreVernant tem estudado o sentido estético, prioritário, com que os antigos dirigiram seus ol hares para o corpo do herói morto em combate. Ú ltimo fulgor da juventude, no momento mesmo em que vêm apagadas todas as manifestações vitais- o vigor, o poder, a força- , na beleza do corpo resplende a "presença divina", fundamental à experiência religiosa mítica. C omo pondera o filósofo, o antropomorfismo dos deuses não significa que fossem concebidos "à imagem do corpo humano" ; para os gregos, pelo contrário,
*Este estudo teve origem na pesquisa 0 s lugares da cidade, sob coordenação da professora Lucrecia D'Alessio Ferrara da FAU -U SP. 
1. Vernant (2000, p. 13), "M ortali e imortali:il corpo divino".

2. Cf. Vernant (2001), especificamente item 1 , "Éídõlon: dal doppio all'immagine".

3. C f.Vernant, "U no, due, tre: Eros", em que o autor comenta: "a relação amorosa constitui para cada indivíduo, no lance que 0 conduz para um outro de si, a experiência da própriaincompletude, enquanto atesta a sua impossibilidade de limitar-se a si mesmo, de contentar-se com aquilo que é, de possuir a própria particularidade, a própria unidade individual, sem buscar desdobrar-se no outro e por meio do outro, objeto do desejo amoroso" (2000, p. 139).
[...] em todos os seus aspectos ativos, em todas as componentes do seu dinamismo físico e psíquico, o corpo do homem remete ao modelo divino como nascente inexaurível de energia vital, cujo fulgor, quando brilha por um instante sobre um mortal, a ilumina com um fugaz reflexo de um pouco daquele esplendor que emana constantemente do corpo dos deuses².

Corpos de extraordinária beleza, templos esplêndidos, os gregos os custodiaram no sólido duradouro - aere perennius, marmore perennius. Primigênio, o kouros arcaico; estátua fúnebre que não consiste propriamente em uma imagem do jovem guerreiro, mas em um duplo do morto. Perpetuado na pedra, nesse monumento que mantém sempre acesa a sua fama eterna, ele não pode ser admirado senão como um corpo sem vida, uma forma inerte, uma " au sência na presença" 2 . Sob o alvor da G récia clássica, adstritos ao valor da imagem como representação (e não mais, cabe reiterar, um duplo do ser divino ou mortal), os escultores almejam seres vivos, insuflando vida, por assim dizer, em suas estátuas. $\mathrm{E}$ malgrado o desterro das artes imitativas propugnado por Platão, também ele, em diferentes circunstâncias, evocará o lume, fascínio e plenitude ínsitos na visão do belo. "A Beleza" - lê-se no F edro - "pudemos vê-la em todo seu esplendor [...]. A qui, temo-la surpreendido, resplandecendo em sua mais luminosa clareza, pelo mais clarividente dos nossos sentidos" (Platão, 1991, pp. 866-867 [250b-d]).

N 0 Banquete, 0 liame entre 0 belo e a imortalidade faz-se preeminente. C abe, por ora, assinalar um tópos que, sobretudo a partir desse diálogo, será recorrente nas indagações so bre a arte e o tempo. Se o amor da Beleza, fala o filósofo pela voz de Diotima, é desejo do bom, "não apenas de tê-lo, mas de tê-lo sempre", se o objeto do amor é a "posse constante do bom", então ele não é propriamente amor da beleza mas" da geração e da parturição no belo". A ção que lhe permite possuir constantemente o bom, só assim ele alcança o bem maior da imortalidade, pois"é desse modo que tudo o que é mortal se conserva [... ]. É por esse meio, Sócrates, que o mortal participa da imortalidade" (Platão, 1966, pp. 162-164 [205a-206e e 208b-c]; 1991, pp. 587-588).

Geração nos corpos, geração na alma, sutil jogo de espelhamentos. 0 s pais se vêem no semblante dos filhos, perpetuam-se neles, no outro de si como um si mesmo. T êm-se assim em um elo de reciprocidades, já anunciado na correspondência de olhares entre os amantes: "no seu amante, como em um espelho, é a si mesmo que ama [...], tendo nele um contra-amor que é uma imagem refletida do amor" (Platão, 1991, pp. 869-870 [255d])33. Em um e outro, o "mesmo" não significa o igual como idêntico a si.Ver-se no outro, ter-se no e pelo outro, jamais implica igualá-lo absolutamente a si. N a arte erótica platônica, a simetria não anula a alteridade. Especulações similares 
convêm aos rebentos da alma. $\mathrm{N}$ a inteligência e demais virtudes, cujos progenitores " são todos os poetas criadores e todos aqueles artesãos que se diz serem inventivos", persegue-se por igual o imperecível. "Todo homem preferiria ter filhos de tal índole a tê-los humanos, se dirige os seus olhos a H omero, a H esíodo ou aos demais bons poetas e contempla com inveja que descendência têm deixado de si mesmos, que Ihes propiciam imortal fama e recordação, sendo eles mesmos o que são" (Platão, 1966, p. 170 [209d-e]; 1991, p. 588)4. Pela educação, artes, política, ciência, filosofia, enfim, os homens progridem nos diferentes estádios da ascese à Beleza em si.

Entre "filhos mais belos e mais imortais", junto a H esíodo e Homero as gerações vindouras reúnem arquitetos e suas criações. Filhos de venerável estirpe, corpos de eterna juventude... Essas duas imagens constituem 0 áxis em torno do qual orbitam idéias superlativas para a moderna concepção de arte (e arquitetura) inaugurada no $\mathrm{R}$ enascimento.

\section{A beleza e o mármore}

Q ue coisa é a belez a? N ão é luz nem noite. É crepúsallo, um parto do verdadeiro e do não verdadeiro. U ma coisa intermediária.

Goethe

Em seu tratado D e re aedificatoria, Leon BattistaA lberti ([1452] 1989) concebe a beleza como uma correspondência tal entre as partes e o todo que nada pode ser acrescentado, subtraído ou alterado sem comprometer a unidade do conjunto $^{5}$. $\mathrm{N}$ a visão do belo assim acolhida (temo-la na letra de Filarete, Francesco Di Giorgio, Leonardo, Palladio e tantos mais) rutila a imagem da perfeição. 0 arquiteto admira nas grandes obras "uma excelência ou perfeição de natureza que estimula o espírito e é subitamente advertida" ; como ele, seus sucessores aditam o epíteto "divina". Por igual inferência, o R enascimento comparte com os antiqui o desejo de salvaguardar a beleza da caducidade das coisas, reconhecendo na imitação (mímesis) sua principal arma. Do recurso ao expedienteVitrúvio (1997) fornecia o testemunho. N o Livro IV do $D$ e architectura, ao advertir os contemporâneos contra os abusos de ornamentação, descrevendo detalhadamente a origem lígnea de cada elemento do templo dórico, ultima:

Desses elementos, e da obra de carpintaria, os artífices com as suas esculturas (scalpturis) nas lapídeas e marmóreas edificações dos sacros tem plos têm imitado as disposições, e têm ajuizado que se devesse seguir tais invenções (V itrúvio, 1997, Livro IV, 2, 2-3, p. 377).
4. Sobreo "amor criativo" e a inexistência na doutrina platônica das idéias de "um posto para uma estética autônoma, uma dêndia da arte" (C assirer, 1998, pp. 46-47).

5. Cf. A lberti ([1452] 1989, livro VI, cap. 2, p. 235; livro IX, cap. 5, p. 453). Sobre a difusão no $R$ enascimento da concepção albertiana de beleza (concinnitas), ver $\mathrm{Pa}$ nofsky (1985c). 
Como 0 estatuário que esculpi na pedra a beleza dos corpos, o arquiteto, "transpondo" em material mais duradouro as disposições dos primeiros templos, não almeja um simulacro ou engano dos olhos, pretende fazer justiça à realidade sagrada e atemporal da beleza. Se se deve falar em simulacro, ele não reside propriamente na contrafação em pedra de algo que ela não é - 0 madeiro, o corpo belo -, mas na ilusão de, pelo espelho lapídeo, 0 artista salvar definitivamente a beleza sensível do transitório das coisas deste mundo. "Tudo tem sua vez e hora..." Ainda assim, desde Palamedes, mítico inventor das letras e das senhas (e, por elas, da voz post-mortem da epístola testamental), a "arte de duplicar", com seus diferentes gêneros de cópia, sempre foi e será um ardil contra a extinção no tempo.

$N$ a tradução do D e architedura feita por C esare C esariano (1521), à citação acima acompanha o comentário:

Q uesta ratione há in si uma Philosophica consideratione: cum sai tute le cose del mundo se tegano: vel si protegano luna per laltra: ideo ob hanc causam habemus sempiternum esse mundum (C esariano, [1521] 1981, L iber Q uartus, C. X LVIIIV).

H á tempos essa inter pretação era compartilhada pelos arquitetos do $\mathrm{R}$ enascimento. Antonio Averlino, dito II Filarete, dedica ao tema um bom número de páginas do primeiro livro de seu tratado. A pós a clássica assimilatio entre arquitetura e corpo humano, tronco das precisões da proporção, 0 autor exorta 0 interlocutor a identificar literalmente 0 edifício com um homem vivo. Tal como o homem, observa Filarete, o edifício necessita de alimento para viver; caso contrário, adoece e morre. 0 enfermo debilita-se e emagrece, o edifício doente apodrece e rui. Sem os devidos cuidados e a contínua manutenção, o corpo vivo, a pouco e pouco, falece.

Q ue isto seja verdadeiro - conclui o arquiteto - considere R oma, onde se vê aqueles edifícios que com maior razão deveriam ser eternos, e porque não tiveram alimento, ou seja, não foram mantidos, estão arruinados (Filarete, [c.1460] 1972, Livro I, p. 30).

Segue uma longa lista de indagações sobre os grandes edifícios do passado então desaparecidos (palácio maior, campidoglio, palácio de $\mathrm{N}$ ero, palácio e teatro de 0 taviano, entre outros), na qual 0 arquiteto invoca reiteradamente a fórmula interrogativa dove è (onde está?). Como notou Liliana Grassi, tal recurso retórico remete ao motivo bíblico do U bi sunt, relacionado à temática da caducidade das coisas, do tempo, da morte; entretanto, no contexto em que Filarete o emprega, o propósito não é despertar pessimismo e desilusão 
diante do mundo, e sim o oposto, zelo pelos" valores da eternidade e da fama, ambos perseguidos com um correto modo de construir" ${ }^{6}$. A quelas obras admiráveis, guardadas na memória graças aos escritores, sobreviveriam caso não caíssem no descuido. D e fama eterna, jazem irremediavelmente ausentes. $M$ as a ilação não se transmuta em desolação: venerando 0 antigo, 0 arquiteto alenta obras perenes, obras com uma vida tão longa quanto a sua fama.

N ão era nova a imagem das ruínas como um "corpo morto". Q ue se recorde a R uinarum descriptio urbis R omae (1452), de Poggio B racciolini, na qual os monumentos decrépitos são comparados ao esqueleto despojado de suas carnes. A qui, como alhures, recobram ânimo as palavras indignadas de Petrarca perante as ruínas de R oma, evocadoras de um "passado de grandeza" e um presente "deplorável" 7 . $\mathrm{N}$ as ilustrações de seu Triumphus temporis, feitas em fins do $Q$ uattrocento e no $C$ inquecento, a imagem alada do deus $C$ hrónos- $K$ rónos, devorador dos próprios filhos - uma invenção do $\mathrm{R}$ enascimento que aí figura pela primeira vez -, guia o cortejo, armada com sua foice funesta, em meio à arquitetura em ruínas (cf. Panofsky, 1985b, pp. 104-105). M as a aguçada sensibilidade com respeito à ação do tempo e à distância que separa o presente daAntigüidade não sega a perspectiva: “ $Q$ uem duvida que $R$ oma poderia levantar-se de novo, bastando para isso conhecer-se a si mesma?" ${ }^{8}$

Edifícios admiráveis, dignos de fama... C omo bem advertiam Vitrúvio e Alberti, para abraçar a fama obras duradouras não bastam9. Filarete ([c.1460] 1972, Livro I, p. 30):

Se dos grandes homens fica a fama, no caso do edifício temos quase um efeito similar: ao seu modo, um pelo outro rende a nós longa fama deles, tal como pelos escritos temos notícia de muitos homens dignos de grande fama devido às grandes coisas que fizeram, isto é, os grandes edifícios que empreenderam; a fama do edifício se deve à sua magnitude e beleza, assim como do homem, pelas grandese belas coisas que tem feito, permanece a fama.

Sempiterna a beleza dos edifícios, eterna a fama! A citação é notável, seja por reenviar-nos ao commento de C esare C esariano, seja pela vertigem a que submete o leitor com o jogo de intercâmbios entre os termos edificio (edifício), lettere (escritos) e grandi signori (grandes homens). Em síntese, as pedras do edifício são similares às da escrita: guardam viva a fama dos homens que 0 erigiram - comitentes e arquitetos, ainda mais, conservam-na mesmo quando desconhecemos quem foram os edificadores. U m pelo outro deliba de igual éter: espelho da beleza e lápide que fala aos pósteros a grandeza dos seus.

É esse o fascínio que as obras antigas exerceram sobre os primeiros humanistas. R egistros vivos de um passado de glória, dos grandes aconteci-

6. N ota de Grassi em Filarete ([c.1460] 1972, livro I, p. 31); ver também "Introduzione", pp.XX$X X I$ eXXXVI-VII.

7. Ver Panofsky (1981) [a carta de Petrarca (1997, II) foi originalmente citada por Mommsen]; Garin (1975, cap. IV eV). A recorrência à imagem chega até $R$ afael, que na $C$ arta a L eão $X$ lamenta sobre "o cadáver desta nobre cidade, um tempo rainha do mundo, hoje espoliada e destroçada as sim miseravelmente"; ver Choay (1995, p. 43).

8. Petrarca (1997, II; ver infra o significado da"imitação dosantigos" propos ta pelo escritor), apud $\mathrm{Pa}$ nofsky (1981, p. 39).

9. Cf. Alberti ([1452] 1989), livro II, Proem.; Vitruvio (1997), Livro III, P roem., 3, e, so bretudo, Livro VI, P roem., 5. 
mentos relatados nos escritos, e, sobretudo, de um modo de vida exemplar (a virtù antiga), suscitam, nos alvores do $R$ enascimento, um interesse "quase não visual" (K rautheimer) pelas obras em si. São fundamentalmente um extraordinário livro de pedras. $\mathrm{N}$ icolau $\mathrm{V}$ pontua $\mathrm{R}$ oma com escritos fixados sobre os monumentos, conferindo à cidade a alcunha de "o Livro Sagrado dos pobres" (B iblia pauperum).A prevalência da literatura na aproximação às obras pretéritas não furta das últimas, porém, a primazia sobre a primeira. M anuel C hrysolarasjustifica em pormenor a superioridade dosvestigia sobre as litterae. $\mathrm{N}$ a C omparação da antiga e da nova R oma (1411), 0 autor ressalta o quanto as contribuições de $\mathrm{H}$ eródoto e outros historiadores não se equiparam às dos monumentos: sobre a capacidade de informação acerca do passado, seus relevos e esculturas, registrando as guerras e os prisioneiros, os festivais, altares e ofertas votivas, "mostram como as coisas eram nos tempos passados e quais as diferenças entre os povos", permitindo ver os trajes que usavam, o tipo de armas e toda sorte de detalhes. Sobretudo, a prevalência dos monumentos deve-se a que "nos garantem o testemunho de tudo o que aconteceu como se fosse no presente" (cf. Loewen, 1999, pp. 52-57; Smith, 1992, p. 159).

$N$ o proêmio ao $D$ e re aedificatoria, A lberti repete, ao seu estilo, 0 argumento de Chrysolaras:

$N$ ão é necessário dizer quanto crédito a arquitetura conferiu aos Latinos e a seu império; diremos apenas que as tumbase, aqui e ali, tudo o mais visível do passado esplendor bastam para fazer-nos reputar verdadei ras muitas notícias dos historiadores antigos, que de outro modo pareceriam por certo menos confiáveis. [...] $\mathrm{N}$ ão existiu um só entre os maiores e mais sábios príncipes que não considerasse a arquitetura um dos meios mais importantes para dar lustro ao próprio nome para os pósteros (A lberti, [1452] 1989, pp. 8-9).

0 monumento captura no duradouro o transitório, aprisiona no permanente 0 fugaz. 0 que a escrita articula para a voz, ele maquina para os olhos. $M$ as o poder mnemônico da arquitetura é majoritariamente superior ao das letras. Por uma parte, assevera-se a sua "melhor visualização dos fatos" em comparação à literatura. Por outra, sua superioridade deve-se ao modo peculiar de presentificação, vale dizer, sua condição de "testemunho" . A permanência dos monumentos, desde sempre, faz de sua presença algo de irreprodutível. Ú nicos, como as tumbas.

0 tema do triunfo da fama sobre a morte por meio de obras e ações memoráveis é recorrente entre os humanistas. $\mathrm{N}$ a tumba de Leonardo B runi, trabalho de Bernardo $\mathrm{R}$ osselino na igreja de Santa C roce, a efígie fúnebre do secretário florentino não traz as mãos unidas sobre o corpo, como na tradição 
medieval, mas as tem sobre sua $\mathrm{H}$ istoria fiorentina, em conformidade com os sarcófagos antigos e paleocristãos nos quais "o emblema do livro significa a imortalização pela cultura" ${ }^{10}$. 0 s mecenas e os príncipes do R enascimento, sabe-se, ostentarão suas insígnias e seus emblemas junto às obras por eles comissionadas, sobretudo os templos, símbolos da renovatio imperii. 0 mesmo Alberti dará materialidade à mais extremada expressão desses novos valores. $\mathrm{N} \mathrm{a}$ igreja de San Francesco, em R ímini, concebe o frontispício como um arco triunfal tripartido, cujos arcos laterais portam os sarcófagos de Sigismondo $M$ alatesta e de sua esposa I sotta, em evidente alusão ao triunfo sobre a morte. $\mathrm{N}$ a lateral do templo, outra seqüência de arcos, contendo sarcófagos com inscrições all' antica destinados aos homens ilustres, cortesãos e humanistas da cida de, finda por converter todo o edifício em um "grandioso panteão de heróis" ${ }^{11}$.

Longevos os monumentos, sempre acesa a fama. Excelsas as belezas, mais intenso o lustro. Por ironia, a superioridade da arte edificatória sobre a escrita segreda também sua desventura: obra única, irreprodutível, e assim, fadada - tal a astúcia do tempo.

$\mathrm{N}$ ão são uniformes os meios de reprodução peculiares a cada gênero artístico. A cópia indefinida de um poema não macula o estilo e o conteúdo do original; com a arquitetura e demais arti del disegno é diferente ${ }^{12}$. Sedutor, aqui, interperlar o passado pela lente da Era da M áquina; que se olhe, por ora, 0 significado clássico. $0 \mathrm{~s}$ antigos são contumazes: é um engano considerar as belas obras como um "produto de cópia". O s copiadores (e os falsificadores) de sempre denigrem a arte com o simiesco (e a simulação) - maior a habilidade, menor o mérito artístico; ignora-se assim o seu arcano: imitar, não copiar. $M$ aso que imita 0 artista? Somente 0 estulto crê que o escritor imita cegamente um único modelo, assevera C ícero na abertura do livro segundo do $D$ e inventione (C icerone, 1998, II, 5-6). Colhendo, "dentre os insignes escritores, dignos de recordação", aquilo que neles se tem como o melhor, o orador age de um modo similar ao famoso Zêuxis. C onvidado pelos habitantes de $\mathrm{C}$ rotona a pintar uma imagem de $\mathrm{H}$ elena para o templo de Juno, Zêuxis solicitou que se colocassem à sua disposição as mais formosas virgens da cidade, dentre as quais escolheu cinco. Então, "transferindo na muda imagem da deusa” a beleza dos exemplares viventes, excedeu em perfeição a tudo o jamais visto.

[Zêuxis] - conclui Cícero - não julgava poder encontrar em um só corpo tudo aquilo que buscava para representar a beleza, pois a natureza não dá a perfeição absoluta a uma só criatura. A ssim, quase temendo não ter o que doar às outras se a uma só concedesse tudo, [a natureza] oferece a cada uma diferentes qualidades, não sem acrescer alguma imperfeição (C icerone, 1998, I, 3- 4, p. 199; cf. Sabbatino, 1997, pp. 15-16).
10. Cf. Chastel, "A 'heroicização' em sentido humanistatem por resultado uma comemoração que já não éa da santidade cristã, nem a exaltação de puros méritos terrestrese'pagãos', mas o elogio da personalidade espiritual que depende igualmente do aspecto profano e religioso da vida" (1982, pp. 64-65).

11. A expressão édeR uddolf W ittkower (1988, p. 45); no projeto original o reclamo à imortalidade era ainda maior. $\mathrm{N}$ os arcos do frontispício ficavam sarcófagos dosfamiliares de Malatesta e no centro do templo, sob a proteção da cúpula, o seu. As sugestões de deificação eglorificação pessoal, quase se sobrepondo à destinação religiosa do edifício, não foram bem recebidas sequer pelos humanistas e artistas da época; cf. C hastel (1982, p. 354).

12. A penasa escultura as semelha-se à escrita. As cópias obtidas com 0 "esvaziado" (molde em gesso feito diretamente sobre a obra original) aproximam- se da "neutralidade" das cópias de um escrito, e não se identificam, de todo, com "falsificações". Entretanto, embora a técnica fosse conhecida desde a Anti- 
güidade, só se difunde no Barroco e, sobretudo, no século X VIII.A té o final do $R$ enascimento nada se comparaà incumbência que Francisco I, rei da França, encarrega a Primaticcio em 1540. Ajudado pelo jovemVignola, 0 arquiteto supervisiona a realização de moldes das" estátuas mais famosas que se via em R oma", enviando-os à residência real de Fontainebleau. Segundo as palavras de Vasari, Fontainebleau converteu-se "quase em uma nova R oma"; cf. H askel e Penny (1981).

13. Cf. Alberti ([1436²] 1989, livro III, § 56, p. 132). 0 autor, porém, não menciona pinturas ou esculturascomo modelo, limitando a imitação dos antigos a ekphrasis - em particular, a inventio - na composição da história, para a qual "a companhia dos poetase oradorestraz aos pintoresmuito benefício"; cf. livro II, § 53, e III, § 53, pp. 107 e 128129; ver também Sabattino (1997, pp. 21-23).

14. Sigo mais de perto a tradução de Sabattino $(1997$, p. 30).
Cônsonos pintor e orador, no De pictura (1435) Leon Battista Alberti narra o episódio de Z êuxis como paradigma do meticuloso estudo da natureza a que se empenha o artista, "com olhos e mente", para bem discernir a "idéia das belezas", reputando néscios os que "tentam granjear fama por si próprios" ${ }^{13}$. C ícero recomenda colher, entre latinos e gregos, soluções que, segundo o reto juízo, têm alcançado máxima excelência e beleza. $\mathrm{N}$ ão se trata de simples colcha de retalhos, adverte reiteradas vezes o escritor; a unidade entre as partes, outrora "partículas errantes", supõe uma ordem de coerência a ser alcançada, um rearranjo integral que venha a iluminar a perfeita disposição do todo. Esse argumento deu aval, no entanto, ao procedimento oposto: se a imitação prima pela ordem do todo, então a preceptística de Cícero fornece o melhor modelo. Contra o radicalismo dos ciceronianos ortodoxos e a degeneração em fórmulas repetitivas e sem élan, autores como H orácio e Sêneca, reiterando, sob nova luz, a comparação entre Z êuxis e a oratória, apressaram-se em salvar a imitatio.

Com diligência, professa H orácio, o poeta compõe os seus versos semeI hante a uma abelha matinal, a sorver néctar de muitas flores para dele verter 0 mel (C armina, IV, 2, 27-32; cf. Sabattino, 1997, p. 30). N a C arta a L ućlio de número 84, Sêneca volta à imagem, precisando o desenho: tal como as abeIhas, "errando de flor em flor a delibar as aptas ao mel", o bem discernir aquilo que colhemos de muitas leituras, reunindo o que é comum e distinguindo os pares ("porque as coisas bem distintas se conservam melhor"), não exime o escritor de "fundir em um único sabor as diversas libações". A excelência da obra reside propriamente na capacidade de alcançar entre as partes e o todo uma consonância integral, uma unidade que, rigorosamente falando, não se manifesta apenas no arranjo do conjunto, mas cinge cada parte com seu timbre peculiar: "de tal modo que, se aparecer qual a fonte em que bebemos, também aparecerá que o nosso escrito tem a sua originalidade independente das fontes" (Sêneca, 2001, Livro XI, 84, 3-6, pp. 603-605) ${ }^{14}$.

Tal a magnificência da imitatio (e, convém frisar, seu arcano): perpetua a memória dos maiores ao tê-los como modelos, mas nunca se rebaixa à cópia servil. 0 distintivo que dá vida à imitação, Sêneca o compara com o tipo de aparência que existe entre familiares:

Ainda, se na tua obra vier a transparecer o autor que admiras e que está impresso profundamente na tua alma, desejaria que a similitude fosse aquela de um filho, não a de um retrato: o retrato é uma coisa morta (Sêneca, idem, 8-9, p. 607).

$\mathrm{N}$ as primeiras luzes do $\mathrm{R}$ enascimento, Petrarca revive esse significado maior da imitação antiga, dedicando-Ihe palavras admiráveis: 
Aquele que imita deve cuidar para que o seu escrito seja semelhante, não idêntico [ao imitado], e que a semelhança não seja como a de um retrato e seu modelo, na qual quanto maior a aparência mais se elogia o artista, mas, propriamente, como a de um filho e seu pai. $N$ este caso, embora costume haver uma grande diferença de traços individuais, uma certa sombra e, como dizem nossos pintores, um ar perceptível sobretudo no rosto e nos olhos gera essa semel hança que nos recorda o pai enquanto vemos o filho, e isso de tal modo que, se ele fosse submetido à medição, comprovar-se-ia que todas as partes eram distintas; al guma qualidade aí oculta tem tal propriedade. Por isso, temos de tomar cuidado para que, quando uma coisa seja parecida, não o sejam muitas, e que o parecido fique oculto de tal forma que só a pesquisa silenciosa da mente possa captá-lo, que ele seja inteligível mais que descritível. D everíamos, portanto, recorrer a outra faculdade e tom interno do homem, evitando as suas palavras. Pois um tipo de semelhança está oculto e outro patente; um faz poetas, o outro śmios (Petrarca, 1997, X X III , 19, 78-94, p. 206) $)^{15}$.

Limiar entre sombra e luz, visível e invisível, diáfano e inefável, recordo e surpresa... São esses os limites em que se perfila a imitação, ou a beleza. N essa divisa, Petrarca concebe o seu programa humanístico. Só aí a aeternitas do belo inscreve-se plenamente no fluir contínuo da vida. $\mathrm{N}$ ão uma efígie muda e vazia dos olhos, refratária à ação do tempo por ceifar do mármore todo veio de vitalidade; mas uma beleza impregnante, de um silêncio loquaz, a nos deixar atônitose, por assim dizer, sem ar. U ma beleza que não paralisa o presente com a feição lapídea do passado, mas o fecunda. N a latência da vida, em suma, o artista busca energia para o seu ofício. M isterioso jogo de espelhosno qual o semblante dosantecessores refulge na exuberância de novos, sem roubar-Iheso lume. Se a arte mantém viva a fama dosantigos, assim o faz não tanto pelo poder de perpetuidade avistado no espelho da pedra, pela infinita reprodução da cópia ou perenidade do monumento - todos sujeitos às astúcias do tempo - , mas por semear na unicidade do vivente a presença do outro.

Embora Filarete não explore as implicações da analogia entre arquitetura e literatura, foi ele quem melhor expressou, no âmbito da arte edificatória, os expedientes da imitação definidos por Petrarca - e, fato curioso, assim o fez seguindo um caminho inverso ao do literato. A este fascinava a possibilidade da semelhança no seio da diferença; ao arquiteto a manifestação da diferença até nos mais veementes zelos por semelhança. $\mathrm{N}$ o rosto retratado por dois pintores, observa Filarete, a fidelidade ao modelo não apaga "Io stile di ciascheduno" (Filarete, [c.1460] 1972, I, 5-20, p. 28). N ão há outra imagem mais reveladora do espírito do tratado. A assimilatio vitruviana entre arquitetura e corpo humano, radicalizada pela identificação do edifício com um "corpo
15. Cf. Gombrich (1985, p. 249); o autor externa: " $N$ ão conheço outra descrição tão notável do caráter misterioso e esquivo da aparência fisionômica" (p. 250). Petrarca escreve a carta em 1366 (ver ainda: “C abe seguir o conselho de Sêneca, e anteso de Horácio, para que escrevamos como as abelhasfazem 0 mel, sem colher as flores mastranformando-asem mel, de modo a fundir em um a multiplicidade e variedade, sendo este um diverso e melhor"; XX III, 19, 94-97, p. 206). 
16. “D e onde procedeu [tal variedade] é um dos segredosque não se sabe, mas creio que Deus assim o fez por mais beleza, isto é, que tantas gerações de homens que são, foram ou serão não se assemelhem uns e outros totalmente em toda particularidade" (Filarete, [c.1460] 1972, I, 1015, p. 25).

17. Cf.R ensselæer (1982, pp. 35-44) [Poussin sintetiza 0 cânone em pintura: "A novidade na Pintura", pondera 0 artista, "não consiste principalmente em um tema nunca visto, mas na boa e nova disposição e expressão, e assim o tema, de comum e velho, se converte em singular e novo."]

18. Sobre a"imitação da natureza" e a "imitação dos antigos" na tradição clássica, do R enascimento às Luzes, ver Warnke (1996, pp. 343-368). vivo", desperta o autor para a absoluta singularidade que cinge a existência de toda construção. "Jamais viste nenhum edifício que totalmente fosse um como outro, nem em similitude, nem em forma, nem em beleza" (I dem, I, 1015, p. 16). Singulares como os viventes, têm na variedade e dessemelhança entre os homens um exemplo a seguir ${ }^{16}$. Imitar a maniera antica, portanto, equivale a operar preceitos artísticos cujo valor reside exatamente em suas infinitas possibilidades expressivas.

R estaurando (ou "inventando") o léxico dascinco ordens- etrusca, dórica, jônica, coríntia e compósita - e a sintaxe das comodulações, a imitação dos antigos rediviva pelos arquitetos tardou a absorver plenamente a riqueza semântica da mímesis. I quattro libri dell'architettura, de A ndrea Palladio, publicado em 1570, alude mais claramente à preceptística clássica. N o último dosquatro o autor recomenda o estudo das inventioni dos edifícios antigos, para, "no momento e lugar apropriados", delas se servir o arquiteto com variedade e coerência, "\& quanto simil variatione sia laudabile, e gratiosa" (Palladio, [1570] 1980, Livro IV, p. 4). C olhida do A rs poetica de H orácio e de outros retóricosilustres, a orientação repõe a sentença: imitar, não copiar ${ }^{17}$. Sobre quem devolveu à arquitetura a belleza e venustà dos antigos Palladio é explícito:

A arquitetura dos tempos de nossos pais, saída daquelas trevas nas quais ficou longamente como sepulta, começou a deixar-se rever na luz do M undo. [...] Bramante foi o primeiro a iluminar a boa e bela arquitetura, que dosAntigos até aquele tempo tinha permanecido oculta [...] (I dem, IV, p. 64, cap. X V II “D el tempio di Bramante").

A confiar no testemunho, só na obra de Bramante os arquitetos consentem que o moderno assimilou o "modo" dos antigos ou, poderíamos dizer, a latente e inefável presença do modelo ("pai") na cópia ("filho"), referida por Petrarca como o lusco-fusco do belo. $\mathrm{N}$ o primeiro R enascimento, porém, mais do que os exempla a arte exalta a imitação da naturez $a^{18}$. C omo mostrou Panofsky (1985c), esse "naturalismo" - visto como a lição maior dos antigosconsistiu o principal obstáculo para o influxo da interpretação metafísica da beleza no orbe da arte.

Se a visão do belo, ao suscitar a suspensão do tempo naquilo que é por natureza efêmero, justifica o "desejo de petrificar" dos artistas, pelo reverso, incrementa, devido à insensatez dessa coincidentia oppositorum, as desconfianças de que a beleza não passa de ilusão e engo do. Embora o objeto admirado se revele a todos sempre como o esplendor da perfeição, os juízos sobre o belo divergem de pessoa para pessoa, parecendo subverter toda medida. Caso exista realmente uma ordo universal, como escapar das 
quimeras, da espécie de torpor onírico que envolve a arbitrariedade dos juízos, alcançado o estado de vigília? Segundo a convicção dos artistas, as oscilações de juízo são postas à prova e depuradas com o rigoroso estudo e observação da natureza.Vislumbrando outro caminho, os neoplatônicos voltam- se para o sentido que a beleza desperta nos espectadores - admiração, arrebatamento, prazer, aut similia.

0 amor do belo

Pela poesia e através dela, pela música e através dela a alma entrevê os esplendores além da tumba; e quando um belo poema enche os olhos de lágrimas, essas lágrimas não são a prova de um excesso de goz o, mas o testemunho de uma melancolia irritada, de uma postulação dos nervos, de uma natureza exilada no imperfeito e que queria possuir imediatamente nesta terra mesma um paraíso revelado.

Charles Baudelaire

A pulsação vital experimentada na arte, a brisa matinal que inspira, feito rebento a encher de viço a perfeição delibada dos pretéritos, esteve no foco de H orácio e Sêneca em notórios escritos a favor do ajuste entre imitatio e varietas. M as foi sobretudo Plotino, na tarda-antigüidade, quem cuidou de não disjungir beleza e vida.

Também neste mundo [... ] a beleza está ínsita mais na luz que resplende sobre a simetria do que na simetria em si. É isto que a torna fascinante. Por que o esplendor da beleza refulge ao máximo grau em um semblante vivo, enquanto em um semblante morto não se vêem mais que os vestígios, embora a carne e a simetria daquele vulto não são ainda desfeitas? E entre as estátuas, por que resultam mais belas as que melhor exprimem a vida do que outras de maior simetria? E um homem feio, se está vivo, não é talvez mais belo do que um homem, embora belo, representado em uma estátua? ${ }^{19}$

Essa luz, esse "acréscimo" à beleza é a Graça, aí residindo a verdadeira fonte do amor. "Toda forma, de per si, é só isso que é.Torna-se porém desejável quando o Bem a colore, dando-Ihe em certo modo a graça e instilando Amor em quantos a desejam" 20.

N o R enascimento, M arsílio Ficino repõe e dá novo vigor às idéias em tela. Em seu comentário ao Banquete de Platão (1469), o neoplatônico toma de 0 rfeu os nomes dados às três $G$ raças ancilares de $V$ ênus, definindo os atributos da beleza como Esplendor, Verdor e Letícia. 0 segundo, explica, versa sobre "figura e cor", pois a beleza "floresce sobretudo no verdor (viriditatem) da juventude" (Ficino, [1469] 1989, Discurso V, 2, p. 90). Pico della M irandola, em outro comentário a uma canzone d'amore de
19. Plotino, E neida,VI 7, 22, 24-32, apud Hadot (1999, pp. 38-39).

20. Idem,VI 7, 22,5-7 [na trad. italiana de R. R a dice (2002) a symmetría grega corresponde à mais abrangente "harmonia"; seguimos, porém, atradução de H adot (1999, pp. 38-40), em que 0 autor comenta: "se amamos é porque algo de indefinível se acrescenta à beleza: um movimento, uma vida, uma aura que a torna desejável e sem os quais a beleza permanece fria e inerte. [...] $\mathrm{N} 0$ amor se tem um 'a mais', existe nele qualquer coisa de injustificado. E isso que nas coisas corresponde a esse a mais é a graça, é a Vida no seu mistério mais profundo"]. Sobre a concepção de arte plotiniana não como "imitação da natureza" mas como "expressão da essência", cf. Grabar (2001, especificamente pp. 43-44). 
Girolamo Benivieri (1486), referenciado no ficiniano, volta à tríade, expondo em pormenor o pensamento: ser verde significa " permanecer e durar no seu ser íntegro e sem transitoriedade alguma"; o homem alcança a plenitude e perfeição do seu ser na juventude, porém, com o correr dos anos, "sempre perdendo mais e mais o seu vigor e integridade, vem a anular-se em tudo". A beleza máxime dos corpos juvenis, objeto de amor e veneração para todos, espelha verdadeiramente a perfeição harmônica perseguida pelos artistas. "Toda coisa composta, enquanto dura no seu ser", observa 0 autor, "[nela] igualmente dura aquela devida proporção que une as suas partes, eV ênus não é outra coisa que esta proporção". H armonia das partes entre si e com o todo não se esgota na conformação física, antes refulge nos" gestos", na "vivacidade" e na"graça" (Ficino, idem, V, 6, p. 101). Do esplendor da beleza emana vida. $M$ as ao contemplarmos a imagem corpórea da perfeição já nos endereçamos à realidade superior de seu modelo, a uma segundaV ênus, melhor, primeira. "O nde está a primeira e verdadeiraV ênus, isto é no mundo ideal, ali se encontra também o verdadeiro verdor, por ser toda natureza inteligível, intransmutável da integridade do seu ser, e em tudo avessa à senilidade" (Pico Della M irandola, [1486] 1994, Livro II, pp. 54-55).

Admirando a imagem de um ser perfeito, duradouro, alheio à transitoriedade, o homem nela reconhece a semelhança com o celestial. A juventude eterna, a natureza divina da imagem Ihe encanta e desperta amor. $\mathrm{N}$ ão um corpo efêmero, vencido pela matéria, mas um ser que participa do divino e herda dele a sua forma. Subtraindo o corpo, reconhecendo na imagem uma pálida semelhança com a suprema perfeição de D eus, o homem compreende igualmente a ascese da alma. Q uando deparamos com um desconhecido, comenta Ficino, "subitamente nos agrada ou não, sem que saibamos a causa desta impressão; porque a alma, impedida com o governo dos corpos, não vê as formas que por natureza estão dentro dela". É essa semelhança com a I déia o que suscita o sentido da perfeição. "A composição do homem na matéria do mundo", ultima o filósofo, "[por estar a matéria] muitíssimo distante do artífice divino, mostra-se indigna daquela figura perfeita. $\mathrm{N}$ a matéria melhor disposta aparece mais semelhante, na outra, menos. [...] neste acordo consiste a beleza, e nesta aprovação 0 amor" (Ficino, [1469] 1989, V, 5, pp. 98-99).

Em diversos momentos, Ficino expõe as contradições do naturalismo em voga na arte. Primeiro, a teoria das proporções harmônicas, reverenciada como princípio único, exclui esteses igualmente legítimas. "Se a disposição das partes só existe nas coisas compostas" - pondera - "nenhuma coisa simples seria bela" (Ficino, idem,V, 3, p. 93); cores puras, um único 
som, as luzes etc. comportam fruição em si mesmos. Ainda, na complexão da obra de arte, a coordenação das partes selecionadas da natureza, acirrando a componente subjetiva na "escolha correta", exacerba por igual o problema da origem da idéia do belo. Em última instância, de onde vem o sentido de conjunto? "[R eunindo numa única figura] a beleza absoluta do gênero humano, que se encontra dispersa em muitos corpos [...] tu [Sócrates] sabes bem que não a possuis graças propriamente aos corpos mas ao espírito" (Idem,VI, 18, p. 181) ${ }^{21}$.

Para o filósofo, a arquitetura felicita o melhor exemplo de operação guiada pela idéia ${ }^{22}$. Alberti havia sido contumaz quanto à prévia concepção (praecogitare, praedefinire, praescribere) da obra a ser edificada, mediante delineamentos (lineamenta) e maquetes (modelo) (cf. A lberti, [1452] 1989, Proem., pp. 5 e 8.; I , 1, pp. 11-12). Com C esare C esariano, o modelo se alça a arquétipo platônico; respaldado na autoridade de Vitrúvio, o comentador vincula as species dispositionis, isto é, as formas de representação gráfica do arquiteto (icnografia, ortografia e cenografia), que "em grego são denominadas idéai" , à sua ambiciosa concepção do desenho como a capacidade de "ver como num espelho o exemplar da coisa que pretendemos figurar ou operar" (cf. C esariano, [1521] 1981, Liber Primus, C. XIIIV²3.

Enquanto forjada na matéria, a perfeição e a excelência da beleza sujeitam-se, de modo inexorável, à caducidade e ao desvanecimento. $\mathrm{N}$ a breve vida em que vem à luz exibe, porém, com clareza, sua descendência superior. R esplandecente, "provoca, do verbo kállos, que quer dizer provoco" , o espectador com a sua graça, assim despertando a rememoração da I déia. No espeIho da matéria, a imagem refletida perde a nitidez do modelo, mas não deixa de reenviar a ele. $\mathrm{N}$ esse contexto, a mímesis clássica recobra integralmente 0 seu matiz metafísico.

Como no jogo de espelhamentos platônico, também em Ficino ([1469] 1989, V, 4, p. 96) o círculo fecha-se quando no semblante amado 0 amante reconhece os traços do pai.

0 nosso espírito, criado com a condição de estar cercado pelo corpo terreno, [...] serve durante muito tempo ao proveito do corpo. [...] D aqui resulta que o espírito não reconhece a luz do rosto divino que sempre resplandece nele, até que, sendo o corpo já adulto e estando desperta a razão, contemple com seu pensamento o rosto de $D$ eus que reluz na máquina do mundo e que é evidente a seus olhos. Por esta consideração é induzido a contemplar aquele rosto de $D$ eus que resplandece em seu interior. E posto que o rosto do pai é grato aos filhos, é necessário que o rosto de D eus Pai seja gratíssimo aos espíritos
21. 0 tema foi ampla e aprofundadamente abordado por Panofsky (1985c, p. 45-66); cf. também Sabbatino (1997, p. 216). Ainda R afael mantém silêncio sobre o problema da origem da idéia de belo, pronunciando um peremptório "no lo so" na carta a Castiglione de 1516.

22. Cf. Ficino ([1469] 1989, V, 5, p. 100): “Primeiro 0 arquiteto concebe em seu espírito a ra zão e, por assim dizer, a idéia do edifício; depois, na medida de suas forças, constrói a casa tal como a concebeu".

23. Tafuri pondera que "a passagem relativa às 'idéias'assimiladasàs'espécies de disposição' pode ser lida como uma toma da neoplatônica que antecipa grande parte da literaturateórica do maneirismo sobre o tema da 'I dea' ou do 'disegno' (pensamosparticularmente em Lomazzo, Zuccari e Scamozzi)" (1978, p. 444).Ver também A lberti, $D$ e statua, e o próprio D e re aedificatoria. 
24. N o D e A more, a reflexão gira em torno da imagem que 0 amante portaconsigo (conforme afórmula de $X$ enofonte; Simpósio, 21-22). "O que ama", expõe Ficino ([1469] 1989, II, 8, p. 45), "esculpi a figura do amado em seu espírito. E as sim o espírito do amante se converte em um espelho no qual brilha a imagem do amado.Ao se reconhecer no amante, 0 amado é empurrado a amar-Ihe". R aptado pela beleza do amado, admirando-o em todos os momentos, 0 amante custodia a vida do outro, e vice-versa. Somente pela "vida daquele que conserva o que ele havia perdido por negligência" pode 0 amante reencontrar a si mesmo. U m não existe sem o outro, assim inscrevendo-o na realidade do seu ser (idem, pp. 41-46). "Ao amar-te me reencontro em ti que pensas em mim, e me recupero em ti que conservas o que havia perdido por minha próprianegligência. E o mesmo fazes tu em mim" (Idem, p. 43). Ficino, em tom brincaIhão, dizia que por amor haviase transformado na forma jovem do amigo Pico della M irandola; $c f$. K risteller (1988, pp. 297 e 303); C hastel (1982, pp. 290-298; 1954).

25. A maturidadenafruição da beleza coordenase ao mote augusteo do
N o C inquecento, essa concepção desfruta de larga aceitação.A divulgadíssima I conologia de Cesare R ipa (1593), redigida no final do século, concebe a bellezz a feminile como uma mulher nua, tendo a cabeça adornada por uma guirlanda de lírios - hieróglifo da beleza segundo Pierio Valeriano - e ligustros (alfenas), numa mão um dardo - símbolo da chaga de amor que, crescendo lentamente, finda irremediável - e noutra um espelho voltado para fora, "sem espelhar- se nele". A chave para a compreensão do estranho gesto com que porta o seu atributo natural está no fato de "a própria beleza feminil ser um espelho, no qual vendo cada um a si mesmo em melhor perfeição, pelo amor da espécie se incita a amar-se naquela coisa, onde se viu mais perfeito, e depois a desejar-se e a fruir-se" (R ipa, [1593] 1992, Parte Prima, pp. 39-40) ${ }^{24}$.

Pela beleza dos corpos e pela beleza da alma, os olhos se voltam para 0 alto. Enquanto aderem às coisas desse mundo, deixam inadvertido, por muito tempo, o verdadeiro semblante da Beleza, mas disso não decorre que tal atividade seja subalterna ou menor. 0 pensamento de Ficino respalda, em boa medida, a "dignificação das artes" promovida pelo R enascimento. C omo o Sócrates pintor, amando e gerando a beleza em suas obras, os artistas depuram-na das imperfeições da matéria, dão-Ihe realidade em manifestações mais excelsas; reconhecem, enfim, sua procedência divina. Esse aprendizado garante a maturidade na intelecção da beleza ${ }^{25}$. N atural ao mundo corpóreo e sujeito à ação do tempo, o desejo de engendrar beleza - 0 amor pela vida ao fim e ao cabo conduz a uma única fonte. Duas asV ênus, dois osA mores, fala Ficino ([1469] 1989, II, 7, p. 40), ambos "honestos e merecedores de elogio, pois um e outro seguem a imagem divina" 26.

D esse ponto de vista, o contraste entre a beleza e o tempo enleva outra perspectiva, diversa do "triunfo sobre a morte" do primeiro humanismo. Por certo, a natureza não perde a dignidade recém conquistada, mas sua excelência e equilíbrio, além de acenar caminho à “imortalidade através da fama", culmina por endereçar os olhos a uma esfera superior. T iciano, que legou uma das mais encantadoras obras so bre a V enus duplex de Ficino, não foi menos sensível ao tema do poder do tempo sobre a beleza sensível, retratado em pinturas onde uma jovem se vê na imagem do espelho ${ }^{27}$. N o curso do Quinhentos e avançado o século seguinte, a permanência do motivo paulatinamente se desliga do espírito amável e jovial com que os artistas do R enascimento cultuaram a beleza. 0 Velho alado, com "dentes de ferro", a portar consigo a grande foice e esse seu novo atributo, nele espelha um só semblante. Efígie gorgônea dos cristãos, exibe sempre a sentença: vanitas vanitatum, et omnia vanitas ("vaidade das vaidades, tudo é vaidade"; E desiastes 1,2). 
festina lente, ou seja, "Ientamente rápido". Só com

E chora [H elena] quando colhe no espelho as rugas senis, e dentro de si indaga como puderam raptá-la duas vezes. $0 \mathrm{~h}$, Tempo devorador, e tu, invejosa V elhice, queres tudo destruir e pouco a pouco consomes toda coisa faz endo-a morrer, rosa dos dentes da idade, de morte lenta.

O víDıo

Q uando o papa Pio II Piccolomini expediu, em 1462, a bula sobre 0 urgente programa de conservação e manutenção dos edifícios e vestigia antigos - associados, desde sempre, ao corpo decrépito - , reuniu entre os juízos dois no mais das vezes conflitantes: os monumentos são um exemplo de excelência a ser seguido, e, por outro ângulo," permitem perceber melhor a fragilidade das coisas humanas" (C hoay, 1995, p. 40). Testemunhos da precariedade das ações e da imprevisibilidade do porvir, as ruínas parecem deslustrar as ambições de fama imortal. A essa ilação conduzia o motivo bíblico do U bi sunt?, evocado por Isaías $(33,18)$ e São Paulo (I Coríntios 1, 20). Sem engano, argüi-se, em vão deixa-se aos pósteros um feito de glória, um legado material. N ada perdura, todos os bens terrenos são transitórios, inconstantes. A o final, toda a ilusão dos bens granjeados em vida se anula.

Se tais receios e ceticismos jamais desapareceram ao longo do $R$ enascimento - impregnam o M omus de Leon B attistaA lberti, contraface de seu D e re aedificatoria, ou o fascínio pelas ruínas no $\mathrm{H}$ ypnerotomachia poliphili, de Francesco C olonna, para citar dois exemplos de vulto - , somente no M aneirismo e no Barroco reconquistam posto de comando, sob o ímpeto da ContraR eforma. Constatando a intensa expressão patética das ruínas na arte do Seis centos - e, em particular, na obra de Joachim du Bellay (Le premier livre des antiquitez de R ome contenant une génerale description de sa grandeur, et comme une déploration de sa ruine) -, Jan Bialostocki (1973, pp. 192-194) conclui:"Asruínas de R oma converteram-se finalmente em um motivo didático: o contemplá-las põe de manifesto a vanidade de todas as coisas terrenas e faz compreender à consciência que a única possibilidade de redenção se acha em D eus" 28.

Sob idêntico páthos, a beleza reduz-se a um bem diminuto, fugaz, uma "felicidade breve". Fulgor a se esvair, símbolo da vida que se consome, porta sempre consigo um sentimento de perda, uma mácula. E aqui, uma vez mais, repõe-se o veredicto bíblico: por sobre o carpe diem (viva o momento) 0 Verbo, os cuidados da fé, o desapego às coisas materiais como verdadeiro caminho para a "felicidade eterna". Tal o significado da miríade de pinturas sobre natureza morta, todas a refletir uma flor que murcha, flor colhida do Livro de Job $(14,2)$ : a maturidade 0 arrojo e a presteza de ação, próprios dos jovens, realizam-se em plenitude, pois não se perdem na ansiedade, moderando-se pela ponderação e prudência no agir. "U m homem que pudesse jactarse da própria vital idade e da própria cautela simultaneamente" , observaEdgar W ind (1985, pp. 123124), "era chamado um puer senex, ou paedogeron, isto é 'jovem velho'"'.

26. Como mostrouW ind (1985, pp. 59-65; 109111), nesse ponto Pico della M irandola afasta-se radicalmente do pensamento de Ficino. A concepção da beleza como discordia concors exclui identificá la como atributo de D eus: "Em Deus não existe beleza porque a beleza inclui em si qualquer imperfeição, ou seja, o ser composto de algum modo. [...] D epois D ele começa a beleza porque começa a contrariedade". Plotino e Ficino, pelo contrário, concebem a beleza verdadeira como "simples e privada de partes".

27. Cf. Panofsky (1992, pp. 90-95). Sobre o "espelho do tempo", ver C esare R ipa, Shakespea re, Bernini, entre outros; ver também Panofsky (1985b, pp. 106-107); 0 estudo do autor sobre a 
pintura A mor sagrado e amor profano permanece referencial (1985a, pp. 189-237).

28. Sobre Alberti e sua concepção da vida como insania, stultitia, ver Garin (1992, pp. 183-192); sobre o ambíguo significado das ruínas e da Antigüidade no "H ypnerotomachia poliphili", cf. Bruschi (1978, pp. 154-157).

29. Ver Sebastián (1989, pp. 95-100; 1995, pp. 329-335). Sobre o poder como vanitas, ver 0 belíssimo "Vanitas" de Praz (2002, pp. 197-211).
Q ue como flor sai e é pisado, e foge como a sombra, e jamais permanece num mesmo estado;

e de Isaías (X L, 6-8):

Soou uma voz de quem me dizia: clama. E eu disse: Q ue hei de clamar?Toda a carne é feno, e toda a sua glória é como a flor do campo. Secou o feno, caiu a flor, porque o hálito do Senhor assoprou nele.Verdadeiramente o povo éfeno: Secouse $o$ feno, e caiu a flor; mas a palavra de N osso Senhor permanece para sempre.

Inúmeras as obras sobre a felicidade breve e a eterna, sobre a caducidade das coisas terrenas e o verdadeiro caminho a ser trilhado. Santiago Sebastián destaca, porém, uma pintura deValdés Leal, artista maior da Espanha do século X VII, emblemática dos novos ventos. I ntitulada J eroglífico de la vanidad, a tela reúne, junto às flores que murcham, símbolos da vangloria (um crânio laureado), da fugacidade do terreno (um putto que sopra bolhas de sabão), das dignidades efêmeras (coroas reais, um cetro e uma mitra) e das riquezas ilusórias (jóias e moedas); todos eles situados na parte inferior do quadro, em torno a livros amontoados sob uma esfera armilar, símbolos da atenção dos homens pelas coisas mundanas, contrapõem-se à imagem do C risto crucificado e do Juízo Final, no alto e ao fundo, descortinada pelo anjo mensageiro.

Entre os livros, Leon Battista A lberti e Sebastiano Serlio ${ }^{29}$. As ruínas cedem lugar às ambições do R enascimento, todas vãs.

Verdor que fenece, flor que murcha; imagens da transitoriedade dos bens terrenos. Todavia, como as jóias com que se adorna, a beleza assume feições mais abstrusas. Sua sedução e encanto, entorpecentes como a própria riqueza, parecem redundar em quimeras. De símbolo genérico do bem que se esvai, particulariza-se no de um bem ilusório, um engano. Em contraste com os valores morais e de fé, o fascínio da beleza física revela-se uma espécie de prazer "em si", "sem fim". M otivo por que, ladeada pela Luxúria, convém aos que perseguem o prazer pelo prazer. 0 espelho do tempo há de desvelar, não um bem efêmero, mas uma fraude.

Entre os oito emblemas da luxúria que Andrea Alciato apresenta em seu E mblematum liber, de 1531, o terceiro versa sobre 0 túmulo da meretriz, qual seja, Lais, famosa prostituta de C orinto que não suportou a passagem do tempo:

- Q ue tumba é esta? D e quem esta urna?

- De Lais de Efira.

- A h! N ão enrubesceu a Parca ao arruinar tanta beleza? 
- N ão mais havia beleza, a tinha segado a idade. A cauta velha já havia consagrado o espelho aV ênus.

- 0 que significa o cordeiro esculpido que a leoa tem aprisionado com as garras na parte posterior?

- N ada, apenas como ela agarra seus amantes: o homem é um cordeiro do rebanho, 0 amante é agarrado pelas nádegas (A Iciato, [1531] 1993, "E mblema LX X II", pp. 108-110) ${ }^{30}$.

Três décadas antes, C esare $\mathrm{R}$ ipa combinava, sem qualquer desconforto, a mencionada imagem platônica da“"B ellezza feminile” ([1593] 1992, pp. 39-40), e um dragão como sinal de desconfiança. "0 dragão", adverte, "mostra que, onde está a beleza, não se deve confiar, pois ali também está o veneno das paixõese da inveja". N a imagem da "Fraude" o autor destila todo o seu malefício:

M ulher com duas faces, uma de bela jovem, outra de velha feia, será nua até os seios e vestida com linho amarelo até o meio da canela, terá os pés similaresaos de águia, e cauda de escorpião visível entre as pernas; na mão direita terá dois corações, e uma máscara na esquerda. C om as duas faces demonstra enganáveis cores e intenções, o linho significa traição, engano e mutação fraudulenta. 0 s dois corações significam as duas aparências do querer e não querer uma mesma coisa. A máscara denota que a fraude faz aparecer as coisas de outro modo daquele que são. A cauda de escorpião e os pés de águia significam o veneno oculto, que fomenta continuamente, como ave de caça, para rapinar outros, ou os bens ou a honra (R ipa, idem, pp 150-151) $)^{31}$.

A cima de tudo, repudia-se a lascívia, o desejo incontinente excitado pelos corpos belos, o impulso irrefreável, a obsessão. São desmedidos os poderes e os enganos da beleza. Presença arrebatadora, como tantas vezes reiterado no R enascimento, é capaz de animar naquele que a contempla uma dependência "doentia" por si mesma. C om poder de Pigmaleão, para retomar a imagem de Gombrich, Leonardo daVinci observa, no Paragone, o enigmático dom dos pintores de suscitar paixões incontroláveis por suas belezas, como sucedeu a um comprador "perdidamente enamorado" por uma pintura que havia feito, e que Ihe pediu para suprimir os atributos sacros "para poder beijá-la sem causar estranheza. Por fim, a consciência do comprador prevaleceu sobre os seus suspiros e luxúrias, mas foi obrigado a retirar o quadro de casa" (Gombrich, 1995, pp. 100-101). C ontra análogo argumento, Andrea Fulvio levanta-se, em 1527, desacreditando a antiga história de que o papa G regório, o Grande havia ordenado que as mais singelas estátuas do paganismo fossem lançadas no T iver para que, "cativados por sua beleza" , os fiéis não
30. Cf. também os emblemas CX XIV (Sobre a felicidade passageira), CLXXXVIII (Q ue mais vale inteligência do que beleza) e CXCV (Convém que se divulgue a boa fama de uma mulher, não sua beleza).

31. Panofsky (1985a, p. 209) trouxe à luz a interpretação proposta por $R$ ipa para as duasV ênus de Ticiano, vistas como "Felicità breve" e "Felicità eterna", objetando: "sem dúvida, o quadro deT iciano não é um documento de moralismo neomedieval, mas de humanismo neoplatônico"; ver também sua análise do quadro de Bronzino 0 descobrimento da luxúria, relacionado à imagem da fraude supracitada (1985b, pp. 110-115). 
32. Vasari (1993, pp. 590-591); C hastel (1988, p. 257), "Gli «jgnudi» di M ichelangelo". Sobre os ritos dioniśacos e apolíneos vinculados à edificação e incêndio de uma cabana rústica, ver R ykwert (2002, pp. 155206), "O s ritos", e D etienne (1988).

33. Por ironia, apagando toda conotação pagã, no amplexo da M orte e da B eleza a C ontra- $R$ eforma igualmente reconhece o símbolo da compaixão, os martírios da Fé. Insinua-se aqui, entre os desejos e devoções dos séculos XVI e XVII, aquela" beleza medúsea" que os românticos cultuarão com incontinente fervor; cf. Praz (1999, pp. 38-46).

34. Vernant (2000, pp. 120-121), "Figure femminile della morte in Grecia” : "Jogo de ausência na presença, obsessão de um ausente que ocupatodo o vosso horizonte e que, porém, não se conseguirá nunca alcançar, porque pertence ao reino do além. É esta a experiência que 0 vivo faz, no luto, do liame com um defunto, desaparecido no além; e tal é também, no enamorado, a experiência do desejo naquele tanto de incompletude que esse comporta, na impossibilidade de ter tudo para si, de pos suir completamente e se afastassem da nova religião (H askell e Penny, 1981, p. 31). M as se a política de repressão religiosa da beleza nua mostrou-se tolerante com as esculturas antigas do Belvedere, com osartistasmodernos, por outra parte, foi inflexível. No carnaval de 1496, atendendo ao "R ogo delle vanità" de Savonarola e ao clamor de fra' Ieronimo, Baccio della Porta, futuro fra' Bartolomeo de San M arco, Lorenzo di C redi "e muitos outros" lançaram às chamas inúmeros desenhos, pinturas e estátuas de nus - "tante pitture e scolture ignude molte di mano di M aestri eccellenti, eparimenti libri, liuti e canz onieri chefu danno grandíssimo", lastimaVasari -, consumidos no simbólico fogo de uma pequena cabana de estipe e outros lenhos, que, "segundo o costume antigo", era feita nas praças e incendiada na noite de terça-feira "con balle amorosi", nas quais, de mãos dadas, homens e mulheres giravam em baladas ${ }^{32}$. C ontra os perigos da beleza vã - pagã - o melhor antídoto é fechar os olhos.

C haga que, "crescendo lentamente, finda irremediável", o vulto envolvente da beleza comuta-se, por fim, nos traços próprios da morte. 0 elo entre amantes, que na tradição platônica despertava para a consciência da incompletude do ser e do "modo como os mortais alcançam a imortalidade" (Platão) isto é, pela geração no corpo e na alma - eclipsa-se sob o torpor de uma beleza nefasta, que cega suas presas mantendo-as absortas integralmente com a plenitude alucinante de sua presença. Veneno dos olhos instilado, convém frisar, pela balia di amor, pelo furor erótico.A smanifestações de amor extremo, de admiração sem fim, culminam nas expressões patéticas do sublime - arruinamento da riqueza e da saúde, mortificação etc. ${ }^{33}$.

A derente aos corpos, colossal nas estátuas, com abnegação os pastores do Senhor repeliram os apelos da beleza, " pagãos". Sem dúvida, desde as figurações primevas do mito perscrutam-se os seus ardis e liames com a morte. C omo expõe Jean-PierreVernant, os gregos individualizam duas formas de desejo partícipes do jogo erótico: "hímeros, o desejo dirigido a um parceiro presente, ou que está para ser satisfeito, e póthos, o desejo nos confrontos de um ausente, ou o desejo que sofre por não poder se apagar: o pranto, a nostalgia" ${ }^{34}$.A obsessão do belo liga-se sobretudo ao segundo. Portando sempre consigo a imagem vívida do amado, com precisão tal que poderia pintar seu semblante sem a necessidade de vê-lo (X enofonte), o seu desejo assimilase à angústia própria do luto, no qual o elo com o ente querido não se desliga nem se completa, portando o fantasma do morto - vívida imagem - como uma " ausência na presença" (retrato simétrico do apego apaixonado do amante pela pintura de Leonardo). Consorte da obsessão, a paúra diante da perda absorve todo desejo no póthos. A miragem da morte - que, cedo ou tarde, há de recair sobre todos - assume a tácita condição de um "luto" permanente, no qual o amante se vota à pessoa amada, um constante pressentimento da 
ausência. Belezas fatais, como a de H elena, tão somente manipulam os poderes peculiares a toda beleza, sempre a se perfilar entre a plenitude e o efêmero, a presença e a ausência, a possessão e a perda, em suma, entre a vida e a morte.

A branda-se no Barroco o fogo das perseguições a vanitas corpórea.A concepção clássica da symmetría como harmonia divina, há tempos assimilada ao corpo de A dão modelado na argila pelo C riador, recupera interesse, sobretudo com os estudos da arquitetura e das proporções do templo de Salomão feitos pelos jesuítas Juan BautistaV illal pando e $\mathrm{H}$ ieronymus Pradus, cujo tratado, amálgama deV itrúvio e dos escritos bíblicos, veio a público em $\mathrm{R}$ oma entre 1596 e 1604. N o entanto, esse período também forjou as primeiras armas para a dessacralização da beleza empreendida no Iluminismo, e, a ela relacionada, a concepção da arte como expressão do Z eitgeist (espírito da época), sempre atinente a um momento histórico determinado e a nospropiciar como que um espelho de seu tempo ${ }^{35}$. N essa senda desviamos nos das divisas aqui perseguidas, rumo à aventura moderna. M as isso não é de todo verdadeiro.

À guisa de conclusão

A beleza é perigosa.

Paulo Leminsk

D isseminam na atualidade formas que buscam atar os edifícios ao tempo. Efeitos de pátina, pseudo-antigüidades de toda sorte (molduras e colunas, mobiliários), uma profusão de elementos decorativos all'antica alastra-se por superfícies as mais diversas - estabelecimentos comerciais, instituições financeiras, bares e restaurantes, prédios residenciais, casas. Q ue tempo dão- nos a ver?Votados a expor marcas do tempo, não denunciam antes o sentido inverso? Artificiais, epidérmicos, cenográficos. Tempo acumulado ou tempo que se persegue? E que distância guarda da frenética corrida contra o tempo dos nossos dias, emblemática nos prodígios da cirurgia plástica (vale dizer, nestes rostos onde jamais se fixam sinais de envelhecimento)? Belezas refratárias ao "sentido do tempo" ou, deveras, sua outra face, reversa?

$\mathrm{N}$ o início do século $X X, 0$ historiador Aloïs $\mathrm{R}$ iegl identificou como traço do homem moderno o seu fascínio pelas "marcas do tempo". Por certo, desde o $R$ enascimento o edifício é visto da perspectiva histórica, vale dizer, seu valor histórico reside propriamente nesse olhar, visumbre de sua distância com relação ao presente e da possibilidade de seus lógoi serem revivescidos ou não na atualidade. A o demarcar, quer uma alteridade radical com o passado, quer uma afinidade (pautada na permanência ou poder de atualização de algumas de suas virtudes), a história constitui a identidade do presente. $M$ as para sempre 0 seu partner sexual. Póthos fúnebre e póthos erótico correspondem exatamente; a figura da mulher ama da, cujaimagem obsessiona e foge, interfere com aquela da morte." Sobre beleza e morte em H elena, ver B ettini e Brillante (2002, pp. 84-85).

35. Cf.G ombrich (1991), "Padre de la historia del arte: lectura de laslecciones sobre estética de G. W. F. Hegel (17701831)"; R ykwert (2002), especificamente capítulos 3 e 5 . 
aos valores histórico e artístico do monumento $\mathrm{R}$ iegl reúne 0 valor de antigo, aquele no qual o objeto está "quase completamente sublimado a um simples mal menor". Tal valor, esclarece, "não adere à obra no seu estado de formação originário, mas à idéia do tempo transcorrido desde que ela foi iniciada, 0 qual se revela sensivelmente nos traços de antigo" (R iegl, 1995, p. 174). M anifesto nos sinais de desgaste, de esmaecimento, o tempo apresenta-se aí como totalmente abstrato, esvaziado de qualquer conteúdo histórico singular.

A fastando- se da atração que a ruína exerceu sobre todo o Setecentos, e, de modo geral, da poética do sublime, o conceito riegliano não repõe as grandes divisas que marcam a discussão sobre a memória na modernidade. $\mathrm{N}$ ão se trata de contrapor à perspectiva histórica do $\mathrm{R}$ enascimento, ou a ratio iluminista, algo de mais autêntico, florescido no terreno das emoções e afetos, do singularmente expressivo. $\mathrm{N}$ ada aqui remete à "rebelião romântica", às dis tinções entre história oficial e memória afetiva, ou, poder-se-ia acrescentar, entre memória voluntária e involuntária. Pelo contrário, para R iegl, uma e mesma disposição de espírito espelha-se nas esteses do histórico e do antigo. No valor de antigo, "o monumento permanece só um substrato perceptível e necessário para criar em seu contemplador aquele estado de ânimo que no homem moderno produz a concepção do natural curso circular do advir e do transcorrer, do emergir do individual pelo geral e da necessidade natural, para este último, de voltar a imergir pouco a pouco no geral" (R iegl, 1995, p. 177). Somente o homem moderno pode experimentar tal sentimento diante da ruína ou do antigo em geral, somente ele, esclarece $R$ iegl, vivencia um tempo sem amarras. "C hama-se histórico tudo o que passou e que hoje não existe mais. [...] tudo o que depois tem lugar é condicionado por isso que existiu antes, e não poderia ser verificado - assim como adveio em realidade sem 0 anel precedente. 0 nó de toda a concepção histórica moderna é exatamente a idéia de desenvolvimento" (I dem, ibidem). 0 valor histórico consignase a um conteúdo, impõe a aferição da relevância histórica do edifício; 0 valor de antigo, por sua vez, não requer conhecimento algum, apenas um aspecto antigo - daí o seu "culto moderno" imperar entre as massas: "a pretensão de validade geral esse novo valor tem em comum com os valores do sentimento religioso" (Idem, pp. 177-178).

Sob o epíteto de progresso, a profissão de fé no desenvolvimento foi 0 lema maior dos séculos XIX e XX - ao menos até a Segunda Guerra M undial, sabe-se.T ranscorrido quase meio século do tom esperançoso das palavras de R iegl, o culto subjugou-se ao "anjo da história", e seus escombros. M aspor que razão o horror diante dos avatares do progresso não corroborou o menos cabo do próprio culto? Ainda, se o fascínio pelos sinais de um tempo passado não mais se coaduna à fé no progresso ou na inevitabilidade histórica do pre- 
sente, tampouco se iguala, como seria de esperar, ao sintoma de nostal gia (póthos fúnebre). A rredio ao presente, o nostálgico mesmo que se iluda sobre o passado tem nele sempre um endereço certo, utópico ou não. 0 melhor equivalente para esse culto abstrato, não orientado a um lugar preciso, é a melancolia. "A tristeza", escreve Freud,

[... ] é geralmente a reação à perda de um ser amado ou de uma abstração equivalente: a pátria, a liberdade, 0 ideal [...]. M as em que consiste o trabal ho executado pela tristeza? [...] 0 exame da realidade mostrou que o objeto amado já não existe e exige que a libido abandone todas as relações com o mesmo [...]. A pliquemos agora à melancolia os conhecimentos que adquirimos do estudo da tristeza. Em uma série de casos, constitui, evidentemente, uma reação à perda de um objeto amado [...], mas não conseguimos distinguir claramente o que o sujeito perdeu e devemos admitir que também a ele é impossível concebê-lo claramente (apud M atos, 1993, p. 165).

Sede de tempo, sedução por um tempo indefinido, desligado da história, do recordo, dos sentimentos; um tempo desconhecido, que adere às coisas na condição de apagá-las e apagar-se imediatamente. Ídolo sem rosto a nos obcecar tem por contrapartida a perda. M as que outra forma do tempo se impõe com maior força na nossa sociedade senão exatamente o quantum abstrato? A indefinição de traços, o vulto nebuloso que obsessiona o homem moderno parece estar nas antípodas da matemática riegliana.

D a "vitória sobre o tempo", e do vago sentimento de perda que a assiste, $\mathrm{M}$ artin $\mathrm{H}$ eidegger tem nos deixado pungentes palavras:

Todas as distâncias no tempo e no espaço se encurtam. Aonde se podia chegar somente depois de semanas e meses de viagem o homem agora alcança em uma noite de vôo. [...] M as essa pressa de suprimir toda distância não realiza uma vizinhança; a vizinhança não consiste de fato na medida da distância reduzida. Isso que, em termos de medida, está menos distante de nós graças à imagem cinematográfica ou à voz do rádio pode permanecer distante. I sso que, em termos de distância, é para nós imensamente remoto pode ser-nos vizinho. U ma pequena distância não é ainda vizinhança. U ma grande distância não é ainda distância (1976, pp. 109-110).

Para tornar-se familiar, não permanecer distante, é necessário um outro tempo... Inevitável aqui a comparação com triunfo análogo. Se o cancelamento do tempo não assegura verdadeira vizinhança, a sua supressão em rostos que "jamais envelhecem" propicia de fato guarida à beleza? C ustodiar nessa 
tez imune às marcas do tempo o semblante pétreo da "sempiterna juventude" significa real mente possuí-la? A final, onde reside a beleza: na simetria, na graça dos gestos, no "ar" do rosto e dos olhos? R esplende mais no fulgor ou no lusco-fusco? Basta a si mesma ou nasce no entreolhar-se do semblante com o seu espel ho? Perguntas todas que nos constrangem a uma última, mais inquietante: a ambição de apagar o tempo, abreviando-se em um vulto menos frágil, mas não tão duradouro quanto o mármore, não finda por dilatar 0 sentimento de impotência diante da morte? 0 s venerados traços de jovialidade confiam a máscara de G orgó. N o entremeio dos velamentos e horizontes postos ao presente, resta indagar o sentido da beleza na vida (e seu duplo).

Referências Bibliográficas

Albertı, Leon Battista. ([1436²] 1989), D a pintura. C ampinas, Editora da U nicamp (trad. A. S. Mendonça). . ([1450] 1972), D e statua. In: . 0 n painting and sculpture, Londres, Phaidon Press (trad. C. Grayson). . ([1452] 1989), D e re aedificatoria. M ilano, II Polifilo, (trad. G. O rlandi).

A lcıATo . ([1531] 1993), E mblemas. M adrid, A kal (ed. e comentário de S. Sebastián, trad. atualizada de P. Pedraza).

Bettini, M \& \& Brillante, C. (2002), II mito di Elena: immagini e racconti dalla G reda a oggi. Torino, Einaudi.

Bialo sto CKI, Jan. (1973), “Arte y vanitas”. In: E stilo e iconografia: contribución a una ciencia de las artes, Barcelona, Barral (trad. J. M. Pomares).

BRUsCHI, Arnaldo. (1978), "H ypnerotomachia poliphili”. In: AA.VV. Scritti rinasamentali di architettura, M ilano, II Polifilo.

CAsSIRER, Ernst. (1998), E idos ed E idolon: il problema del bello e dell'arte nei dialoghi di Platone. M ilano, R affaello Cortina Ed. (trad. A. Pinotti).

Cesar IAn o, Cesare. ([1521] 1981), D i Ludo Pollione de architectura libri dece traducti de latino in vulgare affigurati: commentati: \& com mirando 0 rdine insignítí. M ilano, II Polifilo (ed. facsímile).

Cicerone, M .T. (1998), D einventione. U niversità di Lecce, M arco Congedo Ed., livro segundo (trad. M. Greco).

Chastel, Andre. (1954), M arsile F iàn et l'art. Genève/ Lille, Livrairie E. D roz/ Livrairie R . Giard. . (1982), A rte y humanismo en F lorencia en la época de L orenzo el M agnífico. M adrid, C átedra (trad. L. Jiménez e L. E. Esteve).

.. (1988). “La morte e la bellezza”. In: . Favole, forme, figure, Torino, Einaudi, pp. 209-268 (trad. M. Zini e M.V. M alvano).

ChoAy, Françoise. (1995), L'allegoria del patrimonio. R oma, O fficina (ed. E. d'Alfonso e L. Valente). 
Detienne, M arcel. (1988), D ioniso a céu aberto. R io de Janeiro, Jorge Zahar Ed. (trad. C. C avalcanti).

FICIN O, M arsilio. ([1469] 1989), D e amore: comentario a "E I B anquete" de Platón. M adrid,Tecnos (trad. R . de laVilla A rdura).

Filarete. ([c. 1460] 1972), Trattato di architettura. M ilano, Il Polifilo (ed.A. M . Finoli e L. Grass;; introd. e notas de Liliana Grassi).

Gar IN , Eugenio. (1975), M edioevo e R inascimento. Bari, Laterza. . (1992), "Studi su Leon BattistaAlberti”. In: R inasite e rivoluz ioni, $\mathrm{R}$ oma, Laterza.

GOM BR ICH, Ernst H . (1985), “El estilo all'antica: imitación y asimilación”. In: N orma y forma: estudios sobre el arte del R enadimiento, M adrid, A lianza Editorial (trad. R emigio G. Díaz). . (1991), Tributos. M éxico, Fondo de C ultura Económica (trad. A . M ontelongo). . (1995), "O poder de Pigmaleão". In: . A rte e ilusão: um estudo da psicologia da representação pictórica, São Paulo, M artins Fontes (trad. R . S. Barbosa).

Grabar, André. (2001), "Plotino e le origini dell'estetica medievale". In: . Le origini dell'estetica medievale, M ilano, Jaca B ook (trad. M . G. Balzarini).

HADOT, Pierre. (1999), Plotino o la sempliatà dello sguardo.Torino, Einaudi (trad. M. Guerra).

H Askel, F. \& Pen ny, N . (1981), Taste and the antique: the lure of dassical saulpture 1500-1900. N ew $\mathrm{H}$ aven, Yale U niversity Press.

HeIdegGer, M artin. (1976), “La cosa”. In: . Saggi e discorsi, M ilano, Gruppo U go M ursia Ed. (ed. G.Vattimo).

KR ISTeller , Paul O. (1988), “Volontà e amor divino”. In: . II pensiero filosófico di M arsilio

Fiano, Firenze, Le Lettere.

Lo EW En, Andrea. (1999), A concepção de didade em L eon B attista A lberti. C ampinas, PU C.

M Atos, O Igária. (1993), “Geometria e melancolia”. In: . 0 iluminismo visionário, São Paulo, Brasilense.

Palladio,Andrea. ([1570] 1980), I quattro libri dell'architettura. M ilano, U Irico H oepli Ed., livro IV, Proêmio (ed. fac-símile).

PAN OFSKY, Erwin. (1981), "'R enascimento': auto- definição ou auto- decepção?”. In:

$R$ enasamento e renascimentos na arte ocidental, Lisboa, Presença (trad. Fernando $\mathrm{N}$ eves). . (1985a), “El movimiento neoplatonico en Florencia y el N orte de Italia”. In: E studios sobre iconologia, M adrid, Alianza (trad. B. Fernández). . (1985b), “El padre tiempo”. In: . Estudios sobre iconologia, M adrid, A lianza (trad. B. Fernández). . (1985c), Idea: contribución a la historia de la teoría del arte. M adrid, Cátedra (trad. M .T. Pumarega). .(1992), “R iflessioni sul tempo”. In: .T iziano: problemi di iconografia,Venezia, M arsilio Ed. (trad. M. Folin).

Petr ar ca, Francesco. (1997), Le familiari. Firenze, C asa Editrice Le Lettere, vols. II e X X III, pp. 203-207 (ed. crítica deV. R ossi). 
Pico Della M IR An do La, Giovanni. ([1486] 1994), C ommento sopra una canz one d'amore. Palermo, N ovecento (ed. P. De Angelis).

Platão. (1966), O B anquete ou do amor. São Paulo, Difusão Européia do Livro (trad., introd. e notas de J. C aval cante de Souza).

. (1991), 0 bras completas. M adrid,Aguilar (trad. M . A raújo, F. G.Yagüe, L. Gil, J. F. M iguez, M. R ico, A. R . H uescar e F. P. Samaranch).

Plotin o. (2003), E nneadi.Verona, Arnoldo M ondadori, livro VI, 7, 22, pp. 1811-1813 (introd. e comentário de G. R eale).

Plutarco. (1958), “Vita di Pericle”. In: .V ite parallele, Torino, Einaudi, vol. I. (trad. C. Carena).

Praz, M ario. (1999), “La bellezza medusea”. In: . La carne, la morte e il diavolo, M ilano, Sansón. . (2002), “Vanitas”. In: . B ellez z a e bizz arria: saggi scelti, M ilano, Arnolfo M ondadori Ed. (ed. A. Gane, introd. de G. Ficara).

R en sselaer, W. L. (1982), “La invención”. In:V t Piđvra Poesis, M adrid, Cátedra (trad. C. L.Tena). R IEGL, Aloïs. (1995), "Il culto moderno dei monumenti: il suo carattere e i suoi inizi". In: Scarrocchia, Sando (ed.), A loïs R iegl: teoria e prassi della conservazione dei monumenti antologia di scritti, discorsi, rapporti 1898-1905, Bologna, Clueb.

R IPA, C esare. ([1593] 1992), I conologia. M ilano,T EA Ed. A ssociati (ed. P. Buscaroni e prefácio de M ario Praz).

R YKWERT, Joseph. (2002), “O s ritos”. In: . A casa de A dão no paraíso: a idéia da cabana primitiva na história da arquitetura, São Paulo, Perspectiva, pp. 155-206 (trad. A. Lima, A. Falbel, M . Goldsztajn, M . D 'A gostino).

Sabbat in O, Pasquale. (1997), "U na vergine di perfetta belleza: l'imitazione nella letteratura e nelle arti figurative del R inascimento". In: . La bellezza di E lena, Firenze, Leo S. Olschki Ed.

Sebast IÁn , Santiago. (1989), “El tema de la vanitas o del desengaño”. In: . C ontrarreforma y barroco: lecturas iconográficas e iconológicas, M adrid, A lianza. . (1995), “La vanidad”. In: . E mblemática e historia del A rte, M adrid, Cátedra.

SêneCA. (2001), Letterea L uálio. M ilano, BibliotecaU niversale R izzoli (trad. enotas de G. M onti).

Sм ITH, Christine. (1992), "Architecture in the culture of early humanism”. In: . E thics, aesthetics and eloquence 1400-1470, Londres, 0 xford U niversity Press.

TAfURI, M anfredo. (1978), "C esare C esariano e gli studi vitruviani nel Q uattrocento". In: AA.VV.Scritti R inasamentali di architettura, M ilano, II Polifilo.

VASARI, Giorgio. (1993), "Vita di Fra' Bartolomeo di S. M arco". In: . Le vite dei più eccellenti pittori, saultori e architetti, $\mathrm{R}$ oma, $\mathrm{N}$ ew Compton.

Ver N AN T, Jean- Pierre. (2000), L'individuo, la morte, l'amore. M ilano, R affaello C ortina Ed. (trad. A. Ghilardotti). . (2001), “La figuradei morti”. In: . Figure, idoli, maschere: il racconto mitico, da simbolo religioso a imagine artística, M ilano, II Saggiatore (trad. A . Zangara). 
Vitruvio. (1997), D e architedura.Torino, Einaudi (ed. P. Gros; trad. e comentário deA. Corso e E. R omano).

W Ar n Ke, M artin. (1996), “Il bello e il naturale: un incontro letale”. In: Settis, Salvatori (ed.). I G red: storia, cultura, arte, sodetà,Torino, Einaudi, tomo I ("N oi e i Greci").

W IN D, Edgar. (1985), M isteri pagani nel R inascimento. M ilano, A delphi (trad. P. Bertolucci). W ItTKower, R udolf. (1988), A rchitectural principles in the age of humanism. Londres/ N ovaYork, A cademy Editions/ St. M artin's Press.

\section{Resumo}

A revivescência do ideal antigo de "fama eterna" e "perpetuidade" da arte propicia na R enascença novos enquadramentos conceituais do princípio clássico da mímesis. A sseverando a proeminência da arquitetura sobre as demais artes, diversos escritos renascentistas vinculam a consecução de obras belas à longevidade das edificações (C hrysolaras, A lberti, Filarete, C esariano, entre outros). A curadoria e o valor exemplar dos monumentos, coordenados ao preceito de imitação dos antichi, suscitam diferentes posicionamentos doutrinários sobre o sentido do tempo na arte, a balizar os classicismos até o século XVIII. U m olhar retrospecto sobre os desafios então lançados permite, em contrapartida, maior distanciamento e juízo crítico acerca do difuso "culto" do tempo e da beleza em voga na atualidade.

Palavras-chaves: R enascimento; A rquitetura clássica; M ímesis; B eleza; Temporalidade; Antigos e modernos.

\section{Abstract}

The revival of the old ideal of "eternal fame" and "perpetuity" in art allowsfor a new conceptual framing of the classical principle of mimesis, in the R enaissance. A sserting the preeminence of Architecture over all the other arts, various renaissance papers link the making of beautiful works to the longevity of the buildings (C hrysolaras, A lberti, Filarete, C esariano, among others). The curatorship and the exemplary value of the monuments, coordinated to the norm of imitating the antichi, bring about different doctrinarian positions on the meaning of time in art to regulate classicisms up to the $18^{\text {th }}$ century. $\mathrm{O}$ the other hand, by looking back on the challenges issued then allows one to make a more removed and critical appraisal on the diffuse "cult" of time and beauty, currently in fashion.

Key words: R enaissance; Classical architecture; M imesis; Beauty; Temporality; Antique and Modern.

Mário Henrique Simão D'Agostino é professor doutor do D epartamento de História da Arquitetura e Estética daFAU U SP. 